Research

\title{
Combination of celecoxib with percutaneous radiotherapy in patients with localised prostate cancer - a phase I study U Ganswindt ${ }^{1}$, W Budach ${ }^{2}$, V Jendrossek ${ }^{1}$, G Becker ${ }^{3}$, M Bamberg ${ }^{1}$ and C Belka*1
}

Address: ${ }^{1}$ CCC Tübingen, Centre for Genitourinary Oncology, Department of Radiation Oncology, University of Tübingen, Tübingen, Germany, ${ }^{2}$ Department of Radiation Oncology, University of Düsseldorf, Düsseldorf, Germany and ${ }^{3}$ Department of Radiation Oncology, Klinik am Eichert, Göppingen, Germany

Email: U Ganswindt - ute.ganswindt@med.uni-tuebingen.de; W Budach - wilfried.budach@uni-duesseldorf.de;

V Jendrossek - verena.jendrossek@uni-tuebingen.de; G Becker - radioonkologie@KaE.de; M Bamberg - michael.bamberg@med.unituebingen.de; C Belka* - claus.belka@uni-tuebingen.de

* Corresponding author

Published: 10 April 2006

Radiation Oncology2006, I:9 doi:10.1186/1748-717X-1-9
Received: 25 November 2005

Accepted: 10 April 2006

This article is available from: http://www.ro-journal.com/content/I/I/9

(C) 2006Ganswindt et al; licensee BioMed Central Ltd.

This is an Open Access article distributed under the terms of the Creative Commons Attribution License (http://creativecommons.org/licenses/by/2.0), which permits unrestricted use, distribution, and reproduction in any medium, provided the original work is properly cited.

\begin{abstract}
Background: Current approaches for the improvement of bNED for prostate cancer patients treated with radiotherapy mainly focus on dose escalation. However molecularly targeted approaches may also turn out to be of value. In this regard cyclooxygenase (COX)-2 inhibitors have been shown to exert some anti-tumour activities in human prostate cancer in vivo and in vitro. Although in vitro data indicated that the combination of COX-2 inhibition and radiation was not associated with an increased toxicity, we performed a phase I trial using high dose celecoxib together with percutaneous radiation therapy.
\end{abstract}

Methods: In order to rule out any increases of more than $20 \%$ incidence for a given side effect level 22 patients were included in the trial. Celecoxib was given $400 \mathrm{mg}$ twice daily with onset of the radiation treatment. Risk adapted radiation doses were between 70 and 74 Gy standard fractionation. RTOG based gastrointestinal $(\mathrm{Gl})$ and genitourinary $(\mathrm{GU})$ acute toxicity scoring was performed weekly during radiation therapy, at six weeks after therapy and three month after completing radiation treatment.

Results: Generally no major increase in the level and incidence of side effects potentially caused by the combined treatment was observed. In two cases a generalised skin rash occurred which immediately resolved upon discontinuation of the drug. No grade 3 and 4 toxicity was seen. Maximal Gl toxicity grade I and 2 was observed in $85 \%$ and $10 \%$, respectively. In terms of GU toxicity $80 \%$ of the patients experienced a grade I toxicity and $10 \%$ had grade 2 symptoms.

Conclusion: The combination of irradiation to the prostate with concurrent high dose celecoxib was not associated with an increased level of side effects. 


\section{Background}

Prostate cancer is the most common malignant tumour in men. At present, approximately 200.000 new diseases are diagnosed per year in the USA leading to the death of more than 30.000 patients. Due to the increased use of PSA screening the number of patients diagnosed in localised disease is rising strongly. Radical prostatectomy, percutaneous radiotherapy and interstitial radiation methods are available for curative treatment of localised stages. Due to a lack of randomised studies, the optimal treatment is still unclear. Based on the available data, however it seems likely that all given methods are more or less equivalent in terms of tumour control. Side effects in the rectum predominate with percutaneous radiotherapy, while mainly impotence and incontinence are seen after prostatectomy [1].

Nevertheless, a crucial problem is still unsolved. The long natural history of prostate cancer makes it difficult to determine which type of local therapy is best in men with life expectancies longer than 8-10 years at diagnosis. In this regard, long-term follow-up data with overall survival as endpoint and meticulous determination of side effects will finally answer the question whether there is an optimal therapy for localised prostate cancer.

Local control rates (defined as biochemically relapse-free five-year survival) between $\sim 50$ and $\sim 90 \%$ can be achieved with percutaneous irradiation for localised stages. All available data indicate the existence of a clear dose-effect relationships for pathological control as well as bNED [2-9]. Hence, strategies for increasing the radiation dose are an important goal when trying to optimise the outcomes after radiotherapy. In order to increase the dose, intensity-modulated radiotherapy or particle based therapy approaches are currently under investigation [10$16]$.

In addition to an increased radiation dose, the blockade of testosterone action was found to be an effective measure for improved radiation treatment results [17-20].

To further optimise the efficacy of radiation treatments, molecular targeted approaches are currently under investigation [21].

Of special importance are drugs targeting tyrosine receptor associated kinase pathways (EGF-R, VEGF-R, IGF-R) downstream kinase molecules, and cell death signalling pathways [22-26]. Beside this, numerous reports underline the importance of prostaglandin signalling during cancer development and growth [27-30]. In addition it has been suggested that the modulation of prostaglandin generation may alter treatment responses towards chemotherapy and radiation [31-34].
A key enzyme involved in prostaglandin synthesis is the inducible cyclooxygenase- 2 molecule which is frequently found to be overexpressed in human cancer cells, whereas in non-malignant tissues COX-2 is predominantly found in association with inflammatory processes [35-37]. The development of selective COX-2-inhibitors thus theoretically allows a tumour specific response modulation.

Based on these findings, COX-2 inhibitors were shown to be effective in patients with FAP, where the number of polyps is strongly reduced when patients received $2 \times 400$ mg celecoxib per day. Importantly lower doses had less effects on the development of adenomas [38].

Although the inhibition of the COX-2 enzyme by celecoxib is important for the understanding of its efficacy, several data suggest that celecoxib may exert nonCOX-related effects in cancer cells [39-43]. In this regard, Waskewich [44] showed that celecoxib induces clonogenic cell kill with similar IC50 values irrespectively of the COX-2 expression status. Although the mechanisms of the non-COX-dependent action of celecoxib are not completely understood, several data suggest that they are related to the fact that celecoxib triggers a new apoptosis mitochondrial apoptosis pathway or interferes with PKB AKT signalling. Especially the pro-apoptotic effect was found to require doses higher than needed for an inhibition of the regular target enzyme. In this regard the data on FAP suppression are important, since there was a clear dose response relationship above the anti-inflammatory dose level.

Although celecoxib seems to be active alone, several groups provided evidence that the drug is considerably more effective when combined with a second anti-tumour treatment option. A comparative study in animals showed that the combination of radiotherapy with COX-2 inhibitors produces a clearly improved response rate when compared to radiotherapy alone. The TCD 50 values (FSA sarcoma xenograft) were found to be halved in case of a combined treatment $[45,46]$.

Antitumour activities of COX-2 inhibitors have been shown for various human malignant tissues including colorectal $[38,47,48]$, breast $[29,49]$, non small cell lung $[50,51]$ and other epithelial cancers $[42,52-54]$.

Therefore the role of the combination of an COX-2 inhibitor with other treatment modalities has mainly been tested in lung cancer, cervical cancer, head and neck cancer and colorectal cancers.

Several lines of evidence point to a role of COX-2 inhibition as treatment approach for prostate cancer $[39,43,55$ 61] (table 1). Histological analysis of prostate carcinoma 
Table I: Overview on the available mechanistic data regarding the activity of coxibes in prostate cancer

\begin{tabular}{|c|c|c|c|c|}
\hline Cancer Type & Treatment & Investigation & Results & Reference \\
\hline LNCaP PC 3 & Celecoxib & In vitro & $\begin{array}{l}\text { Increased cell death/ } \\
\text { apoptosis }\end{array}$ & Kamijo 200I \\
\hline PC 3 & Celecoxib & In vitro/Xenograft & $\begin{array}{l}\text { GI block/reduced DNA } \\
\text { synthesis/growth inhibition } \\
\text { by COX-2 independent } \\
\text { mechanism }\end{array}$ & Patel 1999 \\
\hline LNCaP PC 3 & Celecoxib & In vitro & Growth inhibition & Srinath 2003 \\
\hline LNCaP PC 3 & Celecoxib & In vitro & $\begin{array}{l}\text { Induction of apoptosis by } \\
\text { blocking Akt activation } \\
\text { independently of } \mathrm{Bcl}-2\end{array}$ & Hsu 2000 \\
\hline PC 3 & Celecoxib+ radiation & In vitro & $\begin{array}{l}\text { Up-regulation of COX-2, } \\
\text { elevated } \mathrm{PGE}_{2} \text { levels after } \\
\text { irradiation }\end{array}$ & Steinauer 2000 \\
\hline LNCaP PC3 DU-I45 & Celecoxib+ radiation & In vitro & $\begin{array}{l}\text { Bax-independent pro- } \\
\text { apoptotic effect of } \\
\text { Celecoxib }\end{array}$ & Handrick 2004 \\
\hline LNCaP DU-I45 PC-3ML & $\begin{array}{l}\text { Celecoxib+ COL-3/ } \\
\text { Docetaxel }\end{array}$ & In vitro/Xenograft & $\begin{array}{l}\text { Augmentation of } \\
\text { chemotherapeutic drug- } \\
\text { induced apoptosis by } \\
\text { activation of caspase } 3 \text { and } \\
9\end{array}$ & Dandekar 2005 \\
\hline
\end{tabular}

cells revealed an overexpression of COX-2 in tumour tissue when compared to normal prostate stroma or benign prostatic hyperplasia [59].

COX-2 contributes to the proliferation of prostate cancer cells, while COX-2 inhibitors were clearly shown to inhibit proliferation and to induce apoptosis [60].

In the setting of hormone refractory prostate cancer the application of celecoxib in patients was associated with some partial PSA responses [62]. Likewise in patients with biochemical relapse after definitive therapy a significant inhibition of serum PSA levels 3 months after treatment with celecoxib was observed [63].

Furthermore, it could be shown in vitro that irradiation of PC-3 cells triggers an increase in COX-2 expression [64]. In own studies, the combination of celecoxib with ionising radiation revealed an additive effect on cell kill in PC3 and DU-145 cells [65].

Based on murine data the combination of celecoxib with irradiation seems not critical regarding toxicity [45]. However, recent clinical data suggest that at least in an multimodality setting the addition of celecoxib to a chemoradiotherapy protocol may be associated with increased toxicity rates [66].

In order to rule out any safety concerns of a combination of celecoxib with irradiation we prospectively determined the toxicity of such an combination in prostate cancer using the highest Food and Drug Administrationapproved dose of $800 \mathrm{mg}$ celecoxib daily.

\section{Methods \\ Aim of the study}

Aim of the study was to determine the acute toxicity of a celecoxib administration during percutaneous radiotherapy of localised prostate cancer. The primary endpoint of the study was the incidence of acute toxicity (up to three months after therapy).

\section{Inclusion and exclusion criteria}

Patients with histologically proven prostate cancer, stages CT1-cT3 cN0 cM0, G1-3, PSA $\leq 20 \mathrm{ng} / \mathrm{ml}$, age up to 75 years and Karnofsky Index $\geq 80 \%$, were included after providing informed consent. Further inclusion criteria were normal levels of hemoglobin, leukocytes, platelets, creatinine, urea, GGT, AP, AST, ALT, bilirubine, creatinine clearance $>50 \mathrm{ml} / \mathrm{min}$ and no other clinically leading secondary disease. Any other NSAIDs were not allowed with the exception of acetylsalicylic acid at a cardioprotective dose. Patients after transurethral resection or prostatectomy and patients with a known contraindication (e.g. gastric ulcer) or allergy to COX-2 inhibitors were excluded. Further exclusion criteria were severe heart, cardiovascular, liver, renal, inflammatory intestinal or blood coagulation disorders, collagenoses, former irradiation of the prostate, secondary malignancies (exception nonmelanotic skin cancer) and regular intake of lithium or fluconazole.

\section{Staging examinations}

The pre-therapeutic staging examinations included the initial PSA value, biopsy with histological confirmation and statement of the grading or Gleason score, rectal digital examination, transrectal endosonography and at least 
Table 2: Target volume and dose concept depending upon stage, grading and PSA

\begin{tabular}{|c|c|c|c|}
\hline Low risk: white & Medium risk: light grey & High risk: dark grey & \\
\hline Stage & $\leq \mathrm{cT} 2 \mathrm{a}$ & $\leq \mathrm{cT} 2 \mathrm{c}$ & cT3 \\
\hline PSA & $\leq 10$ & $<20$ & $<20$ \\
\hline G I Gleason 2-3 & Prostate & $\begin{array}{l}\text { Prostate \& base of seminal vesicles } \\
\qquad 70 \mathrm{~Gy}\end{array}$ & $\begin{array}{c}\text { Prostate \& base of seminal vesicles \& visible } \\
\text { tumour } 74 \text { Gy }\end{array}$ \\
\hline G 2 Gleason 4-6 & Prostate & $\begin{array}{l}\text { Prostate \& base of seminal vesicles } \\
\qquad 70 \mathrm{~Gy}\end{array}$ & $\begin{array}{c}\text { Prostate \& base of seminal vesicles \& visible } \\
\text { tumour } 74 \text { Gy }\end{array}$ \\
\hline G 3 Gleason > 6 & $\begin{array}{l}\text { Prostate \& base of seminal vesicles } \\
\qquad 70 \mathrm{~Gy}\end{array}$ & $\begin{array}{l}\text { Prostate \& base of seminal vesicles } \\
\qquad 70 \mathrm{~Gy}\end{array}$ & $\begin{array}{c}\text { Prostate \& base of seminal vesicles \& visible } \\
\text { tumour } 74 \text { Gy }\end{array}$ \\
\hline
\end{tabular}

pelvic sonography, alternatively computed tomography (CT) or magnetic resonance imaging (MRI), to evaluate the lymph nodes. At PSA levels $>10 \mathrm{ng} / \mathrm{ml}$ a bone scintigraphy was mandatory.

\section{Treatment course}

All patients were treated with celecoxib $400 \mathrm{mg}$ twice daily in an open-label, unblinded trial during the entire series of radiation. The intake of celecoxib was started on the first day of radiotherapy, continued also on radiation-free days (e.g. weekends) and stopped on the last day of radiotherapy. Celecoxib medication was discontinued, if a patient developed $\geq$ grade 3 toxicity. The percutaneous radiotherapy was planned with a three-dimensional (3D) radiation planning system based on computed tomographies in supine position. A rectal balloon filled with $40 \mathrm{ml}$ of air was used in order to spare the posterior wall of the rectum and for fixation of the prostate [67]. An additional $3 \mathrm{D}$ radiation planning without the rectal balloon was performed simultaneously for use in case of non-tolerance of the balloon. We used a conformal, isocentric 4-field technique with $15 \mathrm{MV}$ photons. Target volume and dose concept depended on a risk classification based on the prognostic factors stage, grading and initial PSA level. The patients received $5 \times 2.0$ Gy per week up to 70.0 Gy and 74.0 Gy cumulative dose, respectively. The planning target volume (PTV) included the risk dependent clinical target volumes (table 2) with a safety margin of $10 \mathrm{~mm}$ (with rectal balloon) and $12 \mathrm{~mm}$ (without balloon), respectively. The patients with a high risk of relapse treated with 74.0 Gy cumulative dose received a boost of 8 Gy with a dorsal safety margin of $5 \mathrm{~mm}$ followed by $66 \mathrm{~Gy}$ as described above. As organ at risk the whole rectum from anal sphincter to the location where the rectum turned horizontally into the sigmoid colon was defined. The given radiotherapy doses were prescribed in line with ICRU Report No 50 and the given volumes complied with the definitions of ICRU Report No 62. Additional hormone therapy could be freely used as part of the study.

\section{Laboratory measurements}

The creatinine clearance was examined prior to inclusion into the study. Prior to treatment start, at week 2, 4, 6 of the combined therapy and 3 months after the end of treatment blood samples were taken. The measurements included a blood count, coagulation parameters and serum levels of electrolytes, creatinine, urea, GGT, AP, AST, ALT and total bilirubine. PSA levels were measured prior to treatment start and after three months.

\section{Measurement of acute toxicity}

Acute toxicity according to RTOG criteria (gastrointestinal, genitourinary) was acquired at least once weekly during the 7-8 week series of radiation treatment, 6 weeks and 3 months after treatment. Beside the clinical examination documented on case report forms we used a standardised questionnaire that had to be filled by the patients at the same time. Beside acute gastrointestinal and genitourinary toxicity according to RTOG criteria any other acute toxicity was described on the case report form. Late toxicity is further ascertained as part of the radiotherapeutic follow-up examination outside the study once a year.

\section{Criteria for discontinuation/statistics}

The acute toxicity data published by Storey et al. [68] with cumulative doses from 70 to 78 Gy were the reference basis for the toxicity to be anticipated in our study. The study was powered to exclude an $>20 \%$ increase in the incidence of grade 3 and 4 acute GI and GU toxicity. Derived from these conditions the following criteria to close the study prematurely were defined: If no grade 4 acute toxicity would occur in 20 patients, the 95\% confidence interval is 0 to $16.8 \%$. The study would then be discontinued, because at $95 \%$ safety acute toxicity of $20 \%$ or more could be ruled out. If exactly one grade 4 acute toxicity would occur, the $95 \%$ confidence interval is 0.1 to $24.9 \%$. The sample size has then to be increased by further 15 patients. If there would remain just one case of grade 4 acute toxicity, the $95 \%$ confidence interval is 0.1 to $14.9 \%$, with one further case 0.7 to $19,2 \%$, i.e. it would not include the critical value of $20 \%$. If two cases of grade 4 toxicity would occur in the first 20 patients, further 15 patients would be recruited. In case of no further grade 3 or 4 toxicity, the $95 \%$ confidence interval is 0.7 to $19.2 \%$. If at least three cases of grade 4 toxicity would occur in just the first 20 patients, the study would be discontinued. 
Table 3: Patients Characteristics

\begin{tabular}{lc}
\hline Characteristics & No. of patients \\
\hline Age & \\
$<67$ & 10 \\
$>67$ & 10 \\
T-Stage & \\
Ic $-2 \mathrm{a}$ & 12 \\
$2 \mathrm{~b}-2 \mathrm{c}$ & 6 \\
3 & 2 \\
Initial PSA & \\
$\leq 10 \mathrm{ng} / \mathrm{ml}$ & 13 \\
$>10 \mathrm{ng} / \mathrm{ml}$ & 7 \\
Gleason Score & \\
$\leq 6$ & 13 \\
$\geq 7$ & 7 \\
Hormonal ablation & \\
Yes & 14 \\
No & 6 \\
\hline
\end{tabular}

Even when treating additional 15 patients the predefined acceptable toxicity level would have been exceeded.

\section{Results}

\section{Patient characteristics}

From 06/2003 to 07/2004 22 patients were included into the study. All 22 patients completed the radiotherapy without treatment break. In all cases the intake of celecoxib started at the first day of radiotherapy in the morning. Within 2 weeks after commencing treatment 2 of the 22 included patients displayed a general exanthema with pruritus. Medication was stopped immediately and the skin rash resolved completely afterwards. Therefore we assumed that this reaction was a drug allergy. Both patients were excluded from the trial. The other 20 patients completed the treatment according to the study protocol with $400 \mathrm{mg}$ celecoxib twice daily. 5 patients received 74 Gy cumulative dose, 14 patients received 70 Gy cumulative dose and 1 patient was treated with 72 Gy. Median age was 67 years (range 49 - 74 years); median initial PSA-level was $8 \mathrm{ng} / \mathrm{ml}$ (range 2,4-18,3 ng/ml). 14 patients received hormone ablative therapy (table 3 ), mostly started before and continued concurrently to radiotherapy. The rectal balloon was tolerated well, 2 patients' radiotherapy treatment was continued without rectal balloon after 40 and $46 \mathrm{~Gy}$, respectively. The resulting dosevolume-histograms of the rectum are shown for all patients in figure 4 .

\section{Acute gastrointestinal and genitourinary toxicity}

No gastrointestinal or genitourinary acute toxicity grade 3 or 4 (RTOG) occurred. Thus we finished patient recruitment after complete treatment of 20 patients. 17 of 20 patients showed a gastrointestinal acute toxicity grade 1.2 of 20 patients showed a gastrointestinal acute toxicity grade 2. Most frequent grade 1 symptom was mild rectal discomfort. Among he 2 patients with grade 2 gastrointestinal toxicity 1 patient had diarrhoea and the other patient required mild analgetics for his rectal symptoms (figure $1)$.

In 16 of 20 patients we observed a genitourinary acute toxicity grade 1, in 2 of 20 patients a genitourinary acute toxicity grade 2 . Most frequent grade 1 symptom was slight dysuria. Among the 2 patients with grade 2 genitourinary toxicity 1 patient had bladder spasms, the other patient presented with a bacterial cystitis 3 weeks after radiotherapy, which completely resolved after treatment with adequate antibiotics (figure 2).

\section{Other toxicity}

Considering the acute skin toxicity we observed 2 patients with a grade 2 toxicity (circumscribed moist desquamation measuring $1-2 \mathrm{~cm}$ per patient), 8 patients with a grade 1 toxicity and 10 patients with no toxicity at all (figure 3). Based on the clinical examinations, the taken blood samples and the questionnaires filled by the patients we observed no other acute toxicity. With exception of the 2 patients described above who developed a drug allergic reaction no cardiovascular, gastric, renal, hepatic or bone marrow side effect of celecoxib occurred.

\section{Discussion}

Several approaches for the improvement of bNED in the radiotherapeutic treatment of localised prostate cancer were tested. Current strategies mainly focus on dose escalation. In this regard, new radiation technologies for example IMRT allow the application of high radiation doses without increasing the toxicity. In addition, the combination with hormonal treatment has been proven to be suitable to increase local control and biochemical relapse-free interval rates. The results of four major trials [18-20], [69-72] revealed that a combined treatment is advantageous for intermediate and high risk patients. Patients with an intermediate risk profile benefit both from radiation dose escalation and additional hormonal treatment, even if there is no clear cut recommendation regarding starting time and duration of hormonal treatment for intermediate risk patients. However molecularly targeted approaches may also turn out to be of value. In this regard, preclinical studies suggest that COX-2 inhibitors have an certain anti-tumour activity when given alone and are even more active when combined with classical anti-tumour treatment.

In case of prostate cancer, a clear dose response relationship exists for the endpoint local control and bNED especially in patients with a low or intermediate risk profile. Although in vitro data indicated that there is no increased toxicity when COX-2 inhibitors are combined [45] with radiation, there are few clinical data concerning the toxic- 


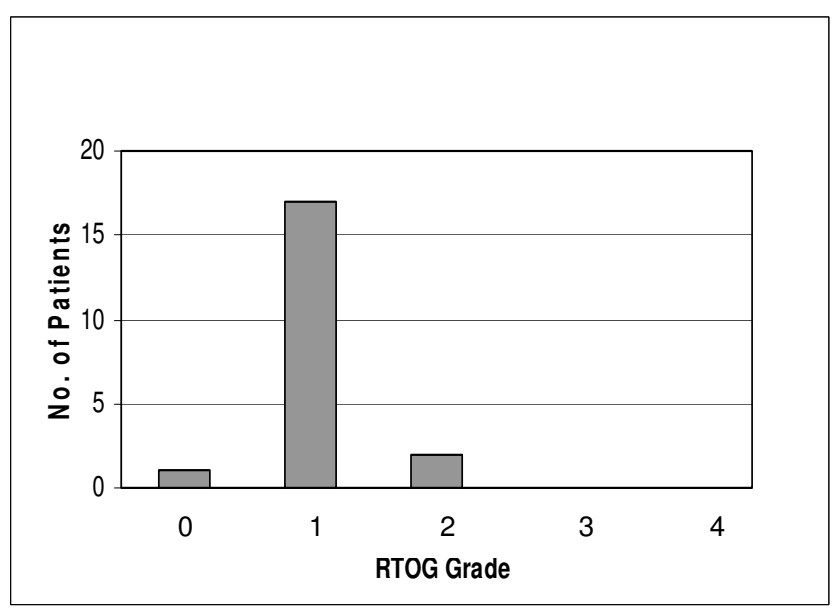

Figure I

Acute gastrointestinal toxicity (RTOG).

ity of a combined treatment. The aim of our prospective trial was to determine the acute toxicity of a simultaneous celecoxib and radiotherapy application.

An $>20 \%$ increase in the incidence of grade 3 and 4 acute GI and GU toxicity could be excluded. We did not observe any grade 3 or 4 toxicity. With exception of 2 patients with a drug allergic reaction no systemic side effects were obvious. The cumulative rates of grade $0-2$ toxicities are in the same range as already documented by others $[14,16,68,73,74]$. However, we observed a larger proportion of grade 1 toxicities (gastrointestinal and genitourinary). This finding may simply reflect a certain lack of precision for the definition of grade 1 effects using the RTOG criteria, allowing inaccuracies when comparing patient sets from different investigators.

Although tested in a rather small cohort, our prospective data suggest that it is save to combine the highest FDA approved dose of celecoxib with intermediate radiation dose concepts for prostate cancer. This observation is in keeping with our clinical impression that, despite a widespread clinical use of coxibes as pain relievers in the past, no major problems occurred.

However, our data do not allow an incautious use of coxibes in other clinical settings. This holds especially true when more complex regimes are taken into account. In this regard, the analysis of the early toxicity of RTOG 0128 treatment arm testing a combination of pelvic radiotherapy, 5-FU, cisplatin and celecoxib for advance cervical cancer revealed major GI toxicity in 50\% of the treated patients [66]. Similarly, a clinical phase I trial at the M.D. Anderson Cancer Center in patients with pancreatic can-

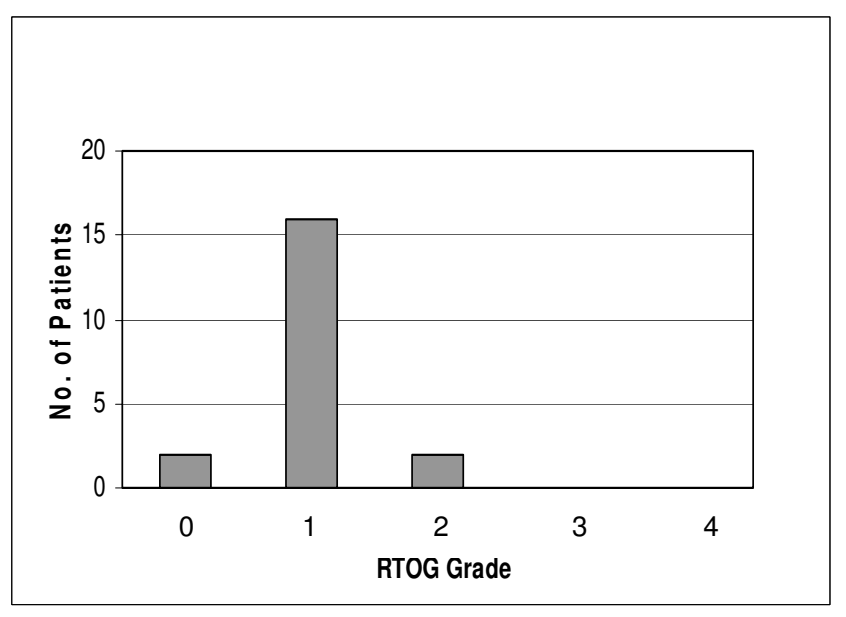

Figure 2

Acute genitourinary toxicity (RTOG).

cer has revealed more toxicity when celecoxib was added to a chemoradiation with gemcitabine [75]. Thus a meticulous toxicity testing should be performed when ever attempting to combine celecoxib with radiation alone and more importantly, when additional cytotoxic drugs are applied.

A different picture emerges from some other phase I/II trials showing that celecoxib combined with radiation or chemoradiation is safe and well tolerated. Liao et al. [76] tested escalated (200-800 mg daily) celecoxib doses combined with thoracic radiotherapy in patients with inoperable NSCLC and showed safe administration of $800 \mathrm{mg}$ celecoxib daily and encouraging preliminary outcome results. An additional phase I/II trial concerning 27 patients with brain metastases treated with radiation and celecoxib [77] confirmed the feasibility and safety. Govindan et al. [78] treated patients with oesophageal cancer with cisplatin, 5-FU and celecoxib and concluded, that the addition of celecoxib to chemoradiation is well tolerated. The results of ongoing phase I and phase I/II trials combining celecoxib with either radiation or radiation plus chemotherapy have to be expected.

Although initially announced to be pain medications with an low and optimal toxicity profile, severe concerns regarding the safety of the coxibes as drug family came up when an increased rate of non-fatal cardiac events was observed in patients treated with rofecoxib for rheumatic disorders over longer periods of time [79]. Unfortunately, these observations seem to have discredited the use of coxibes over a short term as putative anti-neoplastic agents. Up to now no data are available on a potential increase in cardiac and vessel related side effect when coxibes are used over a short time period and in higher doses. Since there 


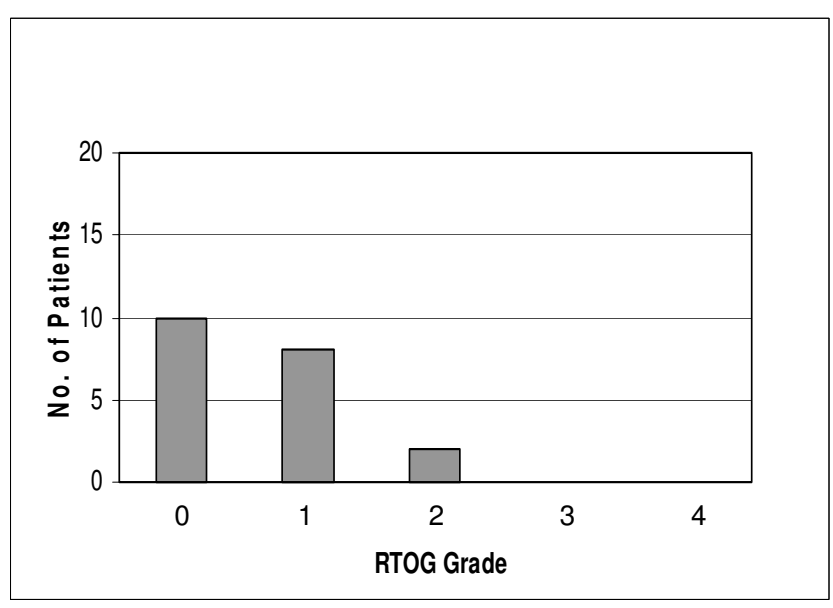

Figure 3

Acute skin toxicity (RTOG).

are no data available to finally judge the value of coxibes in oncology we find it not justified to suspend clinical testing of coxibes in an oncology setting based on the results from long term use in rheumatology. This is even more underlined by the fact that the comparatively high toxicities are acceptable for anti-neoplastic drugs when compared with simple pain relievers.

\section{Conclusion}

In comparison with published data the toxicity of a combination of high dose celecoxib and radiotherapy for prostate cancer is not increased. Further phase II and III testing is required for efficacy testing.

\section{Abbreviations}

AP Alkaline phosphatase

AST Aspartat-Aminotransferase

ALT Alanin-Aminotransferase

BNED Biochemical no evidence of disease

CT Computed tomography

CTV Clinical target volume

EGF-R Epidermal growth factor receptor

FAP Familial adenomatous polyposis

5-FU 5-Fluorouracil

G Grading

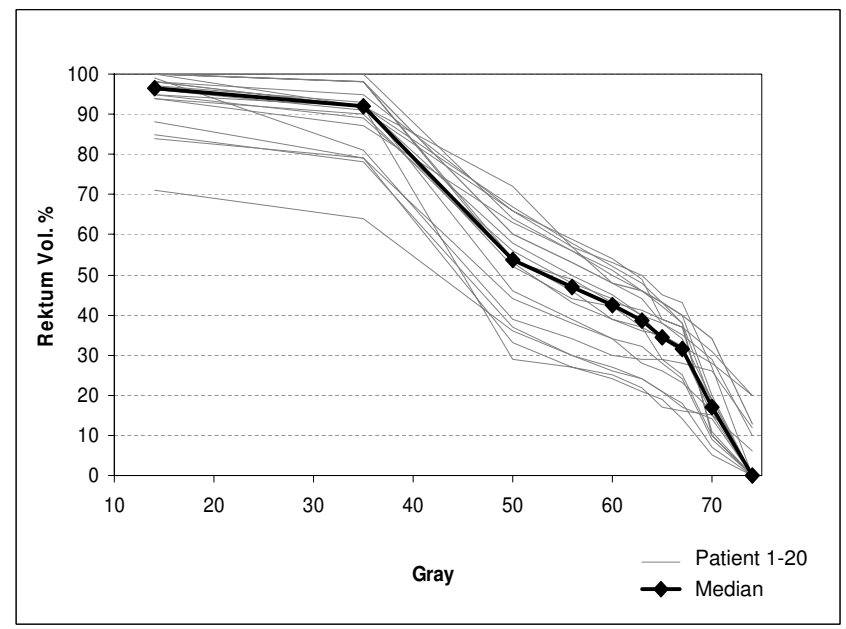

Figure 4

Dose-volume-histograms of the rectum.

GGT Gamma-Glutamyltransferase

Gy Gray

IC 50 value Inhibitory concentration of $50 \%$

ICRU International Commission on Radiation Units and Measurement

IGF-R Insulin-like growth factor receptor

mg Milligram

MRI Magnetic resonance imaging

NSAID Non steroidal anti-inflammatory drugs

NSCLC Non-small-cell- lung-cancer

PSA Prostate specific antigen

PTV Planning target volume

RTOG Radiation Therapy Oncology Group

TNM Tumour/nodal/metastases stage

TCD 50 Radiation dose yielding $50 \%$ tumour cure

VEGF-R Vascular endothelial growth factor receptor

\section{Competing interests}

The author(s) declare that they have no competing interests. 


\section{Authors' contributions}

WB, CB \& UG, VJ planned, coordinated and conducted the study. UG analysed the data. UG \& CB prepared the manuscript. Medical care was covered by UG, CB, WB \& MB. All authors read and approved the final manuscript.

\section{Acknowledgements}

The trial was supported by Pfizer Pharmaceuticals; CTN: COXAON-0509082-GERMANY. Celecoxib (Celebrex ${ }^{\circledR}$ ) was provided by Pfizer.

\section{References}

I. Potosky AL, Legler J, Albertsen PC, Stanford JL, Gilliland FD, Hamilton AS, Eley JW, Stephenson RA, Harlan LC: Health outcomes after prostatectomy or radiotherapy for prostate cancer: results from the Prostate Cancer Outcomes Study. I Natl Cancer Inst 2000, 92: I 582-1592.

2. Fiveash JB, Hanks G, Roach M, Wang S, Vigneault E, McLaughlin PW, Sandler HM: 3D conformal radiation therapy (3DCRT) for high grade prostate cancer: a multi-institutional review. Int J Radiat Oncol Biol Phys 2000, 47:335-342.

3. Valicenti R, Lu J, Pilepich M, Asbell S, Grignon D: Survival advantage from higher-dose radiation therapy for clinically localized prostate cancer treated on the Radiation Therapy Oncology Group trials. J Clin Oncol 2000, I 8:2740-2746.

4. Kupelian PA, Buchsbaum JC, Reddy CA, Klein EA: Radiation dose response in patients with favorable localized prostate cancer (Stage TI-T2, biopsy Gleason $<$ or $=6$, and pretreatment prostate-specific antigen $<$ or $=10$ ). Int $J$ Radiat Oncol Biol Phys 200I, 50:62I-625.

5. Zelefsky MJ, Fuks Z, Hunt M, Lee HJ, Lombardi D, Ling CC, Reuter VE, Venkatraman ES, Leibel SA: High dose radiation delivered by intensity modulated conformal radiotherapy improves the outcome of localized prostate cancer. J Urol 200I, 166:876-881.

6. Pollack A, Zagars GK, Starkschall G, Antolak JA, Lee JJ, Huang E, von Eschenbach AC, Kuban DA, Rosen I: Prostate cancer radiation dose response: results of the M. D. Anderson phase III randomized trial. Int J Radiat Oncol Biol Phys 2002, 53:1097-II 05.

7. Levegrun S, Jackson A, Zelefsky MJ, Venkatraman ES, Skwarchuk MW, Schlegel W, Fuks Z, Leibel SA, Ling CC: Risk group dependence of dose-response for biopsy outcome after three-dimensional conformal radiation therapy of prostate cancer. Radiother Oncol 2002, 63: II-26.

8. Hanks GE, Hanlon AL, Epstein B, Horwitz EM: Dose response in prostate cancer with 8-1 2 years' follow-up. Int J Radiat Oncol Biol Phys 2002, 54:427-435.

9. Ganswindt U, Paulsen F, Anastasiadis AG, Stenzl A, Bamberg M, Belka C: 70 Gy or more: which dose for which prostate cancer? J Cancer Res Clin Oncol 2005, 131:407-419.

10. Ganswindt U, Paulsen F, Corvin S, Eichhorn K, Glocker S, Hundt I, Birkner M, Alber M, Anastasiadis A, Stenzl A, Bares R, Budach W, Bamberg M, Belka C: Intensity modulated radiotherapy for high risk prostate cancer based on sentinel node SPECT imaging for target volume definition. BMC Cancer 2005, 5:91.

II. Cella L, Lomax A, Miralbell R: Potential role of intensity modulated proton beams in prostate cancer radiotherapy. Int J Radiat Oncol Biol Phys 200I, 49:217-223.

12. Xia P, Pickett B, Vigneault E, Verhey LJ, Roach M: Forward or inversely planned segmental multileaf collimator IMRT and sequential tomotherapy to treat multiple dominant intraprostatic lesions of prostate cancer to $\mathbf{9 0} \mathbf{~ G y}$. Int J Radiat Oncol Biol Phys 200I, 5 I:244-254.

13. Slater JD, Rossi CJJ, Yonemoto LT, Bush DA, Jabola BR, Levy RP, Grove RI, Preston W, Slater JM: Proton therapy for prostate cancer: the initial Loma Linda University experience. Int J Radiat Oncol Biol Phys 2004, 59:348-352.

14. Zietman AL, DeSilvio ML, Slater JD, Rossi CJJ, Miller DW, Adams JA, Shipley WU, Yonemoto LT, Mantik DW, Bush DA, Preston W, Grove RI, Slater JM: Comparison of conventional-dose vs high-dose conformal radiation therapy in clinically localized adenocarcinoma of the prostate: a randomized controlled trial. Jama 2005, 294:1233-1239.
15. Mock U, Bogner J, Georg D, Auberger T, Potter R: Comparative treatment planning on localized prostate carcinoma conformal photon- versus proton-based radiotherapy. Strahlenther Onkol 2005, 181:448-455.

16. Zelefsky MJ, Fuks Z, Hunt M, Yamada Y, Marion C, Ling CC, Amols $\mathrm{H}$, Venkatraman ES, Leibel SA: High-dose intensity modulated radiation therapy for prostate cancer: early toxicity and biochemical outcome in 772 patients. Int J Radiat Oncol Biol Phys 2002, 53:IIII-III6.

17. Bolla M, Gonzalez D, Warde P, Dubois JB, Mirimanoff RO, Storme G, Bernier J, Kuten A, Sternberg C, Gil T, Collette L, Pierart M: Improved survival in patients with locally advanced prostate cancer treated with radiotherapy and goserelin. $N$ Engl J Med 1997, 337:295-300.

18. Bolla M, Collette L, Blank L, Warde P, Dubois JB, Mirimanoff RO, Storme G, Bernier J, Kuten A, Sternberg C, Mattelaer J, Lopez Torecilla J, Pfeffer JR, Lino Cutajar C, Zurlo A, Pierart M: Long-term results with immediate androgen suppression and external irradiation in patients with locally advanced prostate cancer (an EORTC study): a phase III randomised trial. Lancet 2002, 360:103-106.

19. Roach M, DeSilvio M, Lawton C, Uhl V, Machtay M, Seider MJ, Rotman M, Jones C, Asbell SO, Valicenti RK, Han S, Thomas CRJ, Shipley WS: Phase III Trial Comparing Whole-Pelvic Versus ProstateOnly Radiotherapy and Neoadjuvant Versus Adjuvant Combined Androgen Suppression: Radiation Therapy Oncology Group 9413. J Clin Oncol 2003, 21 : | 1904-191I.

20. Lawton CA, DeSilvio M, Roach M, Uhl V, Krisch R, Seider M, Rotman M, Jones C, Asbell S, Valicenti R, Han S, Thomas CR: An update of the phase III trial comparing whole-pelvic to prostate only radiotherapy and neoadjuvant total androgen suppresion : Updated analysis of RTOG 94-13. Int J Radiat Oncol Biol Phys 2005, 65:S 19.

2I. Belka C, Jendrossek V, Pruschy M, Vink S, Verheij M, Budach W: Apoptosis-modulating agents in combination with radiotherapy-current status and outlook. Int J Radiat Oncol Biol Phys 2004, 58:542-554.

22. Lammering G: Anti-epidermal growth factor receptor strategies to enhance radiation action. Curr Med Chem Anti-Canc Agents 2003, 3:327-333.

23. Belka C, Gruber C, Jendrossek V, Wesselborg S, Budach W: The tyrosine kinase Lck is involved in regulation of mitochondrial apoptosis pathways. Oncogene 2003, 22:176-185.

24. Marini P, Jendrossek V, Durand E, Gruber C, Budach W, Belka C: Molecular requirements for the combined effects of TRAIL and ionising radiation. Radiother Oncol 2003, 68: I89-198.

25. Marini P, Schmid A, Jendrossek V, Faltin H, Daniel PT, Budach W, Belka C: Irradiation specifically sensitises solid tumour cell lines to TRAIL mediated apoptosis. BMC Cancer 2005, 5:5.

26. Jendrossek V, Müller I, Eibel H, Belka C: Intracellular mediators of erucylphosphocholine-induced apoptosis. Oncogene 2003, 22:262|-263।.

27. Gupta $S$, Crofford L): An update on specific COX-2 inhibitors: the COXIBs. Bull Rheum Dis 200I, 50:I-4.

28. Dannenberg AJ, Altorki NK, Boyle JO, Dang C, Howe LR, Weksler $\mathrm{BB}$, Subbaramaiah K: Cyclo-oxygenase 2: a pharmacological target for the prevention of cancer. Lancet Oncol 200I, 2:544-55I.

29. Howe LR, Subbaramaiah K, Brown AM, Dannenberg AJ: Cyclooxygenase-2: a target for the prevention and treatment of breast cancer. Endocr Relat Cancer 200I, 8:97-I I4.

30. Thun MJ, Henley SJ, Patrono C: Nonsteroidal anti-inflammatory drugs as anticancer agents: mechanistic, pharmacologic, and clinical issues. J Natl Cancer Inst 2002, 94:252-266.

31. Petersen C, Baumann M, Petersen S: New targets for the modulation of radiation response--selective inhibition of the enzyme cyclooxygenase 2. Curr Med Chem Anti-Canc Agents 2003, 3:354-359.

32. Pyo H, Choy H, Amorino GP, Kim JS, Cao Q, Hercules SK, DuBois RN: A selective cyclooxygenase-2 inhibitor, NS-398, enhances the effect of radiation in vitro and in vivo preferentially on the cells that express cyclooxygenase-2. Clin Cancer Res 2001, 7:2998-3005.

33. Davis TW, Hunter N, Trifan OC, Milas L, Masferrer JL: COX-2 inhibitors as radiosensitizing agents for cancer therapy. $\mathrm{Am} J$ Clin Oncol 2003, 26:S58-6I. 
34. Milas L, Mason KA, Crane CH, Liao Z, Masferrer J: Improvement of radiotherapy or chemoradiotherapy by targeting COX-2 enzyme. Oncology (Williston Park) 2003, I7:15-24.

35. Futaki N, Takahashi S, Yokoyama M, Arai I, Higuchi S, Otomo S: NS398, a new anti-inflammatory agent, selectively inhibits prostaglandin G/H synthase/cyclooxygenase (COX-2) activity in vitro. Prostaglandins 1994, 47:55-59.

36. Williams CS, Mann M, DuBois RN: The role of cyclooxygenases in inflammation, cancer, and development. Oncogene 1999, | 8:7908-79|6

37. Siegle I, Klein T, Backman JT, Saal JG, Nusing RM, Fritz P: Expression of cyclooxygenase I and cyclooxygenase 2 in human synovia tissue: differential elevation of cyclooxygenase 2 in inflammatory joint diseases. Arthritis Rheum 1998, 4I:122-129.

38. Steinbach G, Lynch PM, Phillips RK, Wallace MH, Hawk E, Gordon GB, Wakabayashi N, Saunders B, Shen Y, Fujimura T, Su LK, Levin B: The effect of celecoxib, a cyclooxygenase-2 inhibitor, in familial adenomatous polyposis. N Engl J Med 2000 342: 1946-1952.

39. Hsu AL, Ching TT, Wang DS, Song X, Rangnekar VM, Chen CS: The cyclooxygenase-2 inhibitor celecoxib induces apoptosis by blocking Akt activation in human prostate cancer cells independently of Bcl-2. J Biol Chem 2000, 275: | I397- I | 403.

40. Jendrossek V, Handrick R, Belka C: Celecoxib activates a novel mitochondrial apoptosis signaling pathway. Faseb J 2003, I 7: 1547-I549.

4I. Grosch S, Tegeder I, Niederberger E, Brautigam L, Geisslinger G: COX-2 independent induction of cell cycle arrest and apoptosis in colon cancer cells by the selective COX-2 inhibitor celecoxib. Faseb J 200I, I 5:2742-2744.

42. Jiang XH, Lam SK, Lin MC, Jiang SH, Kung HF, Slosberg ED, Soh JW, Weinstein IB, Wong BC: Novel target for induction of apoptosis by cyclo-oxygenase-2 inhibitor SC-236 through a protein kinase C-beta(I)-dependent pathway. Oncogene 2002, 21:6II3-6I22

43. Song X, Lin HP, Johnson AJ, Tseng PH, Yang YT, Kulp SK, Chen CS: Cyclooxygenase-2, player or spectator in cyclooxygenase-2 inhibitor-induced apoptosis in prostate cancer cells. J Natl Cancer Inst 2002, 94:585-591.

44. Waskewich C, Blumenthal RD, Li H, Stein R, Goldenberg DM, Burton J: Celecoxib exhibits the greatest potency amongst cyclooxygenase (COX) inhibitors for growth inhibition of COX-2negative hematopoietic and epithelial cell lines. Cancer Res 2002, 62:2029-2033.

45. Kishi K, Petersen S, Petersen C, Hunter N, Mason K, Masferrer JL, Tofilon PJ, Milas L: Preferential enhancement of tumor radioresponse by a cyclooxygenase- 2 inhibitor. Cancer Res 2000 60:|326-|33|

46. Milas L, Kishi K, Hunter N, Mason K, Masferrer JL, Tofilon PJ: Enhancement of tumor response to gamma-radiation by an inhibitor of cyclooxygenase-2 enzyme. J Natl Cancer Inst 1999 9I:150I-1504.

47. Sheng H, Shao J, Kirkland SC, Isakson P, Coffey RJ, Morrow J, Beauchamp RD, DuBois RN: Inhibition of human colon cancer cell growth by selective inhibition of cyclooxygenase-2. J Clin Invest 1997, 99:2254-2259.

48. Richter M, Weiss M, Weinberger I, Furstenberger G, Marian B: Growth inhibition and induction of apoptosis in colorecta tumor cells by cyclooxygenase inhibitors. Carcinogenesis 200I, 22:17-25.

49. Hwang D, Scollard D, Byrne J, Levine E: Expression of cyclooxygenase- $I$ and cyclooxygenase- 2 in human breast cancer. J Natl Cancer Inst 1998, 90:455-460.

50. Soslow RA, Dannenberg AJ, Rush D, Woerner BM, Khan KN, Masferrer J, Koki AT: COX-2 is expressed in human pulmonary, colonic, and mammary tumors. Cancer 2000, 89:2637-2645.

5I. Lin MT, Lee RC, Yang PC, Ho FM, Kuo ML: Cyclooxygenase-2 inducing Mcl-I-dependent survival mechanism in human lung adenocarcinoma CLI .0 cells. Involvement of phosphatidylinositol 3-kinase/Akt pathway. I Biol Chem 200I, 276:48997-49002.

52. Komhoff M, Guan Y, Shappell HW, Davis L, Jack G, Shyr Y, Koch MO, Shappell SB, Breyer MD: Enhanced expression of cyclooxygenase-2 in high grade human transitional cell bladder carcinomas. Am J Pathol 2000, I 57:29-35.
53. Nzeako UC, Guicciardi ME, Yoon JH, Bronk SF, Gores G]: COX-2 inhibits Fas-mediated apoptosis in cholangiocarcinoma cells. Hepatology 2002, 35:552-559.

54. Souza RF, Shewmake K, Beer DG, Cryer B, Spechler SJ: Selective inhibition of cyclooxygenase-2 suppresses growth and induces apoptosis in human esophageal adenocarcinoma cells. Cancer Res 2000, 60:5767-5772.

55. Pruthi RS, Derksen E, Gaston K: Cyclooxygenase-2 as a potential target in the prevention and treatment of genitourinary tumors: a review. J Urol 2003, 169:2352-2359.

56. Liu XH, Yao S, Kirschenbaum A, Levine AC: NS398, a selective cyclooxygenase-2 inhibitor, induces apoptosis and down-regulates bcl-2 expression in LNCaP cells. Cancer Res 1998, 58:4245-4249.

57. Gupta S, Srivastava M, Ahmad N, Bostwick DG, Mukhtar H: Overexpression of cyclooxygenase-2 in human prostate adenocarcinoma. Prostate 2000, 42:73-78.

58. Yoshimura R, Sano H, Masuda C, Kawamura M, Tsubouchi Y, Chargui J, Yoshimura N, Hla T, Wada S: Expression of cyclooxygenase-2 in prostate carcinoma. Cancer 2000, 89:589-596.

59. Lee LM, Pan CC, Cheng CJ, Chi CW, Liu TY: Expression of cyclooxygenase- 2 in prostate adenocarcinoma and benign prostatic hyperplasia. Anticancer Res 2001, 21:1291-1294.

60. Kamijo T, Sato T, Nagatomi Y, Kitamura T: Induction of apoptosis by cyclooxygenase- 2 inhibitors in prostate cancer cell lines. Int J Urol 200I, 8:S35-9.

61. Patel MI, Subbaramaiah K, Du B, Chang M, Yang P, Newman RA, Cordon-Cardo C, Thaler HT, Dannenberg AJ: Celecoxib inhibits prostate cancer growth: evidence of a cyclooxygenase-2independent mechanism. Clin Cancer Res 2005, I I:1999-2007.

62. Dawson NA, Slovin SF: Novel approaches to treat asymptomatic, hormone-naive patients with rising prostate-specific antigen after primary treatment for prostate cancer. Urology 2003, 62 Suppl I: $102-118$

63. Pruthi RS, Derksen JE, Moore D: A pilot study of use of the cyclooxygenase-2 inhibitor celecoxib in recurrent prostate cancer after definitive radiation therapy or radical prostatectomy. BJU Int 2004, 93:275-278.

64. Steinauer KK, Gibbs I, Ning S, French JN, Armstrong J, Knox SJ: Radiation induces upregulation of cyclooxygenase-2 (COX-2) protein in PC-3 cells. Int J Radiat Oncol Biol Phys 2000, 48:325-328.

65. Handrick R, Jendrossek V, Goecke B, Faltin H, Daniel P, Budach W, Belka C: Effects of celecoxib and irradiation treatment on prostate cancer cell lines. Radiotherapy and Oncology 2004, 73:372-372.

66. Gaffney D, Winter K, Dicker A, Miller B, Jhingran A, Ryu J, Avizonis VN, Fromm M, Greven K: A Phase I-II Study of COX-2 Inhibitor, Celebrex (Celecoxib) and Chemoradiation in Patients With Locally Advanced Cervical Cancer: Primary Endpoint Analysis of RTOG 0128. Int J Radiat Oncol Biol Phys, 2005, 63:S93-S94.

67. Wachter S, Gerstner N, Dorner D, Goldner G, Colotto A, Wambersie $A$, Potter $R$ : The influence of a rectal balloon tube as internal immobilization device on variations of volumes and dosevolume histograms during treatment course of conformal radiotherapy for prostate cancer. Int I Radiat Oncol Biol Phys 2002, 52:91-100.

68. Storey MR, Pollack A, Zagars G, Smith L, Antolak J, Rosen I: Complications from radiotherapy dose escalation in prostate cancer: preliminary results of a randomized trial. Int J Radiat Oncol Biol Phys 2000, 48:635-642.

69. Lawton CA, Winter K, Murray K, Machtay M, Mesic JB, Hanks GE, Coughlin CT, Pilepich MV: Updated results of the phase III Radiation Therapy Oncology Group (RTOG) trial 85-3I evaluating the potential benefit of androgen suppression following standard radiation therapy for unfavorable prognosis carcinoma of the prostate. Int J Radiat Oncol Biol Phys 200 I, 49:937-946.

70. Pilepich MV, Winter K, John MJ, Mesic JB, Sause W, Rubin P, Lawton $C$, Machtay M, Grignon D: Phase III radiation therapy oncology group (RTOG) trial 86-10 of androgen deprivation adjuvant to definitive radiotherapy in locally advanced carcinoma of the prostate. Int / Radiat Oncol Biol Phys 200I, 50: I243-1252.

7I. Horwitz EM, Winter K, Hanks GE, Lawton CA, Russell AH, Machtay M: Subset analysis of RTOG 85-3I and 86-10 indicates an advantage for long-term vs. short-term adjuvant hormones for patients with locally advanced nonmetastatic prostate 
cancer treated with radiation therapy. Int J Radiat Oncol Biol Phys 200I, 49:947-956.

72. Hanks GE, Pajak TF, Porter A, Grignon D, Brereton H, Venkatesan V, Horwitz EM, Lawton C, Rosenthal SA, Sandler HM, Shipley WU: Phase III trial of long-term adjuvant androgen deprivation after neoadjuvant hormonal cytoreduction and radiotherapy in locally advanced carcinoma of the prostate: the Radiation Therapy Oncology Group Protocol 92-02. J Clin Oncol 2003, 21:3972-3978.

73. Ryu JK, Winter K, Michalski JM, Purdy JA, Markoe AM, Earle JD, Perez CA, Roach M, Sandler HM, Pollack A, Cox JD: Interim report of toxicity from 3D conformal radiation therapy (3D-CRT) for prostate cancer on 3DOG/RTOG 9406, level III (79.2 Gy). Int J Radiat Oncol Biol Phys 2002, 54:1036-1046.

74. Koper PC, Stroom JC, van Putten WL, Korevaar GA, Heijmen BJ, Wijnmaalen A, Jansen PP, Hanssens PE, Griep C, Krol AD, Samson MJ, Levendag PC: Acute morbidity reduction using 3DCRT for prostate carcinoma: a randomized study. Int J Radiat Oncol Biol Phys 1999, 43:727-734.

75. Crane $\mathrm{CH}$, Mason $\mathrm{K}$, Janjan NA, Milas L: Initial experience combining cyclooxygenase-2 inhibition with chemoradiation for locally advanced pancreatic cancer. Am J Clin Oncol 2003, 26:S8I-4.

76. Liao Z, Komaki R, Milas L, Yuan C, Kies M, Chang JY, Jeter M, Guerrero T, Blumenschien G, Smith CM, Fossella F, Brown B, Cox JD: A phase I clinical trial of thoracic radiotherapy and concurrent celecoxib for patients with unfavorable performance status inoperable/unresectable non-small cell lung cancer. Clin Cancer Res 2005, I I:3342-3348.

77. Cerchietti LC, Bonomi MR, Navigante AH, Castro MA, Cabalar ME, Roth BM: Phase I/II study of selective cyclooxygenase-2 inhibitor celecoxib as a radiation sensitizer in patients with unresectable brain metastases. J Neurooncol 2005, 71:73-8I.

78. Govindan R, McLeod H, Mantravadi P, Fineberg N, Helft P, Kesler K, Hanna N, Stoner C, Ansari R, Fox E: Cisplatin, fluorouracil, celecoxib, and RT in resectable esophageal cancer: preliminary results. Oncology (Williston Park) 2004, I 8: I8-21.

79. Bresalier RS, Sandler RS, Quan H, Bolognese JA, Oxenius B, Horgan K, Lines C, Riddell R, Morton D, Lanas A, Konstam MA, Baron JA: Cardiovascular events associated with rofecoxib in a colorectal adenoma chemoprevention trial. N Engl J Med 2005, 352:1092-1102

\section{Publish with Bio Med Central and every scientist can read your work free of charge}

"BioMed Central will be the most significant development for disseminating the results of biomedical research in our lifetime. "

Sir Paul Nurse, Cancer Research UK

Your research papers will be:

- available free of charge to the entire biomedical community

- peer reviewed and published immediately upon acceptance

- cited in PubMed and archived on PubMed Central

- yours - you keep the copyright

Submit your manuscript here:

http://www.biomedcentral.com/info/publishing_adv.asp
BiolMedcentral 